\title{
The Status Quo of Doctoral Education in Universities in Zimbabwe
}

\author{
Evelyn Chiyevo GARWE \\ Zimbabwe Council for Higher Education (ZIMCHE) Harare, Zimbabwe \\ E-mail: garweec@gmail.com OR ecgarwe@zimche.ac.zw
}

Tel: 263-772-222-298/263-458-1994

Received: April 21, 2015 Accepted: May 30, 2015 Published: August 1, 2015

doi:10.5296/jse.v5i3.7645 URL: http://dx.doi.org/10.5296/jse.v5i3.7645

\begin{abstract}
Globally, the importance of highly qualified human resources (holders of doctoral degrees) in providing the requisite skills for knowledge economies is well acknowledged. Sadly, African universities are reportedly lagging behind in terms of satisfying the required quantity and quality of doctoral graduates (Harle, 2013). This study was aimed at providing empirical evidence on the status of doctoral education in Zimbabwe as well as identifying the reasons for the status quo. Documentary evidence and telephonic interviews were used to collect data from all the 15 registered universities in Zimbabwe. The interviews involved doctoral students enrolled in local universities as well as in foreign universities, aspiring doctoral candidates and senior academics based in local universities. The findings showed that six out of the $15(40 \%)$ universities were offering programmes at doctoral level in 2014 giving a share of $0.2 \%$. The combined doctoral degree enrolment was 150 translating to a share of $0.18 \%$ of the total student enrolments. A total of 28 people graduated with doctorates from Zimbabwean universities in 2014. Approximately 565 academics from Zimbabwean universities were pursuing doctoral degrees at universities in the region notably in South Africa and Zambia and yet only one university in Zimbabwe enrolled students from the region. The reasons for this state of affairs included the stringent regulatory environment regarding doctoral study in Zimbabwe, shortage of supervisors due to brain drain, unavailability of doctoral programmes at $60 \%$ of the local universities and inadequate funding and resources. The study the study recommends that ZIMCHE and universities should revisit their standards and regulations. In addition, government needs to adequately remunerate university staff and provide funding for research and doctoral studies.
\end{abstract}

Keywords: Doctoral education, university, regulatory environment, supervision, brain drain 


\section{Introduction}

The critical role of universities in producing graduates who contribute to the economic and social development of knowledge economies is well recognised(Kotecha, Steyn \&Vermeulen (2012).To this end the government of Zimbabwe has attempted tosatisfy this need by increasing the number of universities from one in 1980 to the current 15 (Garwe, 2015) resulting in an increase of student enrolments from 2240 to 85556 (ZIMCHE, 2015). However, unconfirmed reports indicate that the shareof students currently enrolled for doctoral studiesand those who graduate with doctorates from local universities is alarmingly low. The need for universities (especially in Africa) to urgently increasethe quantity and qualityof doctoral graduates has featured prominently in a number of discussion forums and reports (Harle, 2013). This stems from the fact thatdoctoral education inculcates the learner with high-level knowledge, attributes and skills which are an essential ingredient in the knowledge economy(Castells, 1993; Gorman 2013).A doctorate is the highest degree awarded by auniversity for independent research and scholarlywork that is subjected to intense supervision, guidance and instruction(Cloete, Sheppard, Bailey \& MacGregor, 2015). The number of doctoral graduates produced is a key criterion in the ranking of universities worldwide. In addition, doctoral studies are positively correlated to the increase in research output which is also one of the most important university ranking criteria.

Universities in Africa tend to concentrate on offering degrees at Bachelors and Masters level at the expense of offering degrees at doctorate level, For example, Gadinger (2012) found a $0.3 \%$ share of doctoral student enrolments in Madagascar with $64 \%$ of these enrolled in science, engineering and technology disciplines.Macgregor (2013) reported that out of the nine universities under study in Sub-Saharan Africa, five of them produced less than 20 doctorates in 2007,three produced between 20 and 40 and one (University of Cape Town) had 100 doctoral graduates.Kotecha et al (2012)estimates that the share of doctoral student enrolments in the Southern African Development Community (SADC) represents a mere $1 \%$ of overall student enrolments and only $0.17 \%$ if South Africa is excluded. Consequently, the contribution of Sub-Saharan Africa to the global scientific research output amounts to only 0.7\%(Macgregor, 2013). In sharp contrast Cyranoski, Gilbert, Ledford, Nayar\&Yahia (2011) reported a 40\% growth rate globally in doctoral graduates between 1998 and 2008, to around 34,000 annually in Organisation for Economic Co-operation and Development (OECD) countries.Rapidly developing countries have a doctoral graduate output of more than $7 \%$ with China (40\%), Mexico (17\%) and Denmark (10\%) increasing at extraordinary (Brushan, 2007)and alarming (Powell \& Green, 2007) rates.Countries that already have high levels of doctorate production were growing at lower rates for example,Canada (1\%), United States of America (2.5\%) and United Kingdom (5.2\%).

One of the major reasons responsible for producing few doctorates in African countries include shortage of supervisors due to brain drain, especially of associate and full professors(IAC Report, 2004). Senior scholars are required to effectively supervise, mentor and to set the research direction for their doctoral students. Other reasons include:unavailability of doctoral programmes at many universities in Africa, high attrition rates (Jiranek, 2010; Kim \&Otts, 
2010); lack of funding and incentives, inadequate infrastructure and equipment as well as poor or non-existent research agendas (MacGregor, 2013).

In view of the situation of low output of doctoral graduates facing many African universities and nations, this study set out todetermine the status of doctoral education in Zimbabwean universitiesand to explore the underlying reasons for the status quo.

\subsection{Definition of terms}

Van't Land (2011)defines the term doctorate or doctoral degreeasthe highest academic qualification awarded to a student after successfully undergoing (under close supervision and guidance) independent research or a combination of course work and independent research on afull or part-time basis. During this period the student contributes to the body of knowledge in the specific field of study and develops research, critical and analytical skills. A doctorate is also referred to as a $\mathrm{PhD}$ or DPhil depending on national or programme context.

\subsection{The role of doctoral education}

Doctoral studies entails tedious and challenging process aimed at transforming learners into scholars and inculcating in them the requisite skills and attributes for effective and productive participation in knowledge economies (Hadjioannou, Shelton, Fu, \&Dhanarattigannon, 2007;Leonard, Becker, \&Coate,2005; Mujtaba, Scharff, Cavico, \&Mujtaba, 2008). Indeed, the doctoral degree is the pinnacle of academic achievement (Hawlery, 2003; Callejo-Pérez, Fain \& Slater, 2011;Jairam\&KahlJr.,2012; Mujtaba et al. 2008; Park,2005). Doctoral degrees are designed to develop students' comprehensive academic competence, socio-emotional abilities, leadership skills, development orientation, language skills, capacity embrace multidisciplinary approach to research and ability apply research results for commercial and social benefits (Brown, 2008; Commission of The European Communities, 2003; Consedine \& Magai, 2006; Stevens-Long, Schapiro, \& McClintock(2012). The production of doctoral graduates is considered to be the most important and prestigious achievement by a university. Halvorsen(2010) refers to universities that have an obligation and public monopoly of awarding doctoral degrees as "research universities."Future academics, leaders, entrepreneurs and champions of industry are developed through doctoral education(Davis, Evans, \& Hickey, 2006; Nettles \&Millett,2006; Thune,2009). Research has shown that usually, people who succeed in obtaining doctoral degrees demonstrate their worth through contributing significantly to their disciplines thus effectively proving themselves to soaring levels(Leonard et al. 2005; Mujtaba et al. 2008).

The standards set by the Zimbabwe Council for Higher Education (ZIMCHE) for teaching staff lecturing and supervising in degree programmes requires that their highest earned academic qualification be at least one level above the exit level of the programmes they are delivering. This translates to a minimum of an appropriate Masters degree for undergraduate programmes and doctoral degree for Masters and doctoral programme. However, studies done in Zimbabwe reported that the proportion of academics holding doctoral qualifications ranged from 3 to $12.5 \%$ depending on university (Garwe, 2013, MoHTE, 2010). Therefore one of the major roles of doctoral education in Zimbabwe is to produce lecturers qualified at 
the highest level who would then assist in developing more doctoral graduates resulting in the multiplier or ripple effect. This agrees well with the argument that doctoral degrees are associated with increased research productivity resulting in publications and patents (Cloete \& Maassen, 2015; Muriisa 2010). MacGregor (2013) therefore suggest that a culture of research at universities is necessary to produce research outputs, and this requires a 'critical mass' of well qualified and committed academics. It is also important to emphasize for optimum results, these academics should operate in conducive environments characterised by: competitive remuneration; manageable workloads; and incentives for research and doctoral student outputs.

\subsection{Doctoral enrolment and throughput}

Several studies in different countries point to low enrolments and low throughput rates of doctoral learners (Albertyn, Kapp \& Bitzer 2008; Lovitts \& Nelson 2000; Mujtaba et al. 2008). The situation of low doctoral enrolments is dire especially in Southern Africa where the share of doctoral student enrolments represents $1 \%$ of overall student enrolments and only $0.17 \%$ if South Africa is excluded (Kotecha et al., 2012;MacGregor, 2013). Low doctoral student enrolments result from several factors including: unavailability of doctoral programmes at many universities; limited numbers of appropriately qualified and motivated supervisors; lack of incentives for students and supervisors; inadequate equipment and other resources to undertake research; lack of consistent and sustainable funding for students and institutions; and lack of institutional and national research agendas (IAC Report, 2004).

Once doctoral students have been enrolled, universities must focus more effort on ensuring that they graduate within reasonable time frames. Unfortunately the general trend globally shows that increasing numbers of enrolled doctoral learners fail to complete on time or abandon studies before completion (Moulton, 2011; Elgar 2003). Therefore the major reasons for low doctoral graduate throughput are: firstly the period of time it takes to complete doctoral studies especially when done on a part-time basis and secondly the low persistence rates or high attrition rates. It is therefore imperative for universities to focus more effort to ensuring that those who register for doctoral studies graduate. Even though doctoral learners are academically capable and are some of the best and sharpest students, having sailed through the extremely challenging selection process (Ali \& Kohun, 2006; Berelson, 1960; Bowen \& Rudenstine, 1992; Gilliam \& Kitronis, 2006; Golde, 2000; Hawlery. 2003), attrition rates are high ranging from $33 \%$ to $88 \%$ (Gardner, 2008; Gardner \&Gopaul, 2012; Golde, 2005; Herman, 2011; Walker, Golde, Jones, Bueschel, \& Hutchings, 2008). Literature reveals that many of the students give up within the first year of studies (Esping, 2010; Jairam\&Kahl Jr, 2012; Lott, Gardner, \& Powers, 2009; Lovitts, 2001). Figure 1 shows an illustration from a study by Bunting \& Sheppard (2012), of the doctoral enrolments, doctoral graduates and research publications in South Africa from 1996 to 2010. 


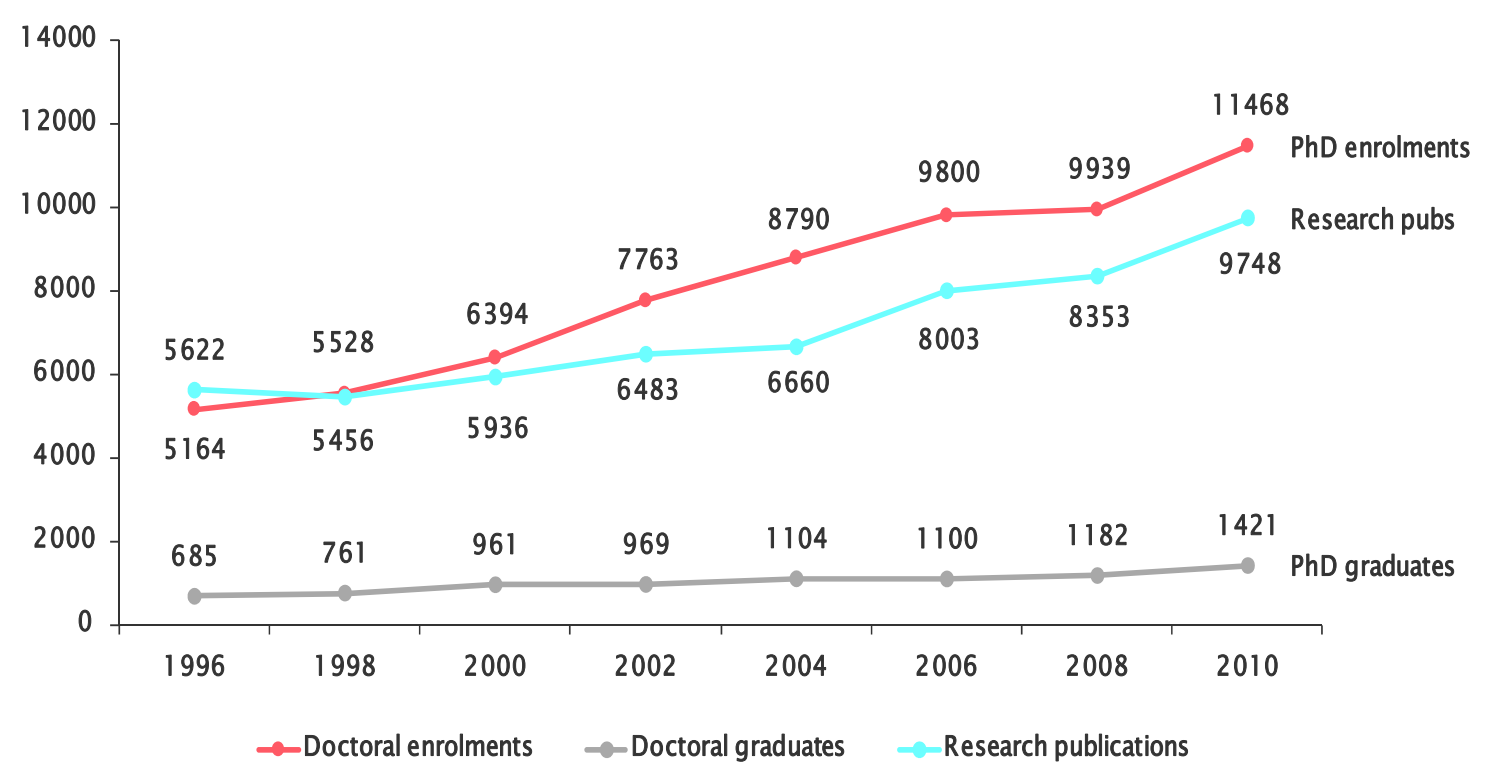

Figure 1. Doctoral enrolments, doctoral graduates and research publications in South

Africa (1996-2010)Source: Bunting \& Sheppard (2012)

Figure 1 clearly shows that although doctoral student enrolments increased from 5164 in 1996 to 11468 in 2010 , doctoral graduates increased from 685 to 1421 during the same period indicating a consistent and alarming attrition rate of $88 \%$. Consistent with Cloete \& Maassen, (2015) assertion that doctoral graduates contribute positively to increased research productivity, Figure 1 reveals an increase of annual research publications from 5622 in 1996 to 9748 in 2010 .

Research shows that attrition of doctoral candidates results from interactions of the individual candidate with the social and institutional environment(Barnes, 2010; Gardner, 2008; Ivankova \& Stick, 2007; Wao, 2010) for example stress (Lovitts, 2001;Oswalt, \& Riddock, 2007) and isolation(Hortulanus, Machielse, \& Meeuwesen, 2006; Jairam\&KahlJr,2012; Lee, 2009; Lewis, Ginsberg, Davies, \& Smith, 2004).

\subsection{Research problem}

Enrolments in doctoral programmes are low in many African countries. Literature shows that the low doctoral output results from unavailability of doctoral programmes at many universities; limited numbers of appropriately qualified and motivated supervisors; lack of incentives for students and supervisors; inadequate equipment and other resources to undertake research; lack of consistent and sustainable funding for students and institutions; lack of institutional and national research agendas as well as high attrition rates. No empirical 
research has been done in Zimbabwe to determine the status of doctoral degrees in Zimbabwe as well as identifying the reasons for the status quo.

\subsection{Research questions}

The objective of this study was to determine the status of doctoral degrees in Zimbabwe as well as identifying the reasons for the status quo. The study explored the following research questions:

1.4.1 What is the number of universities in Zimbabwe that offer doctoral programmes

1.4.2 What are the disciplines in which doctoral studies are offered in local universities?

1.4.3 What is the share of enrolments and graduation statistics for doctoral students in Zimbabwe?

1.4.4 What is the estimate of academics in universities in Zimbabwe that are pursuing doctoral studies with universities outside the country?

1.4.5 What are the reasons for the status of doctoral education in Zimbabwe?

\section{Methodology}

The study included all the 15 registered universities in Zimbabwe and employed two data-collection techniques namely:

- Review of documents from ZIMCHE with respect to:programmes offered by universities; enrolment and graduation statistics; annual reports for universities as well as other relevant documents and databases. The data was the analysed in order to respond to the first three research questions. The most current (2014)enrolment and graduation statistics were used for the analysis.

- Telephonic interviews with doctoral students enrolled in local universities as well as foreign universities, aspiring doctoral candidates and senior academics based in local universities (responding to the fifth and last research question).

\subsection{Procedure}

The researcher first send out requests for information on the contact telephone numbers of doctoral students enrolled in local universities and the number of academics in universities in Zimbabwe that are pursuing doctoral studies with universities outside the country (responding to the fourth research question). The requests were made via email to Directors of Postgraduate Studies or the Registrars (for universities without the post of Director of Postgraduate Studies). Responses were received via the same communication channel.

Using information collected on the number of students in local (150) and foreign (595) universities, a sample representing $15 \%$ of the students was selected. This resulted in 23 local and 90 foreign doctoral students being earmarked for interviews. Five lecturers per university (total of 75) from different academic disciplines who were holders of Masters degrees and therefore aspiring to obtain doctoral degrees were also earmarked for interviews. The 


\section{Macrothink}

Journal of Studies in Education

ISSN 2162-6952

2015, Vol. 5, No. 3

telephone numbers that were provided were dialled and any number that was unreachable after three attempts was skipped. In some cases some prospective respondents refused to participate in the interview. Consequently, a total of 20local, 50 foreign doctoral students and 45 doctoral aspirants were successfully interviewed. Two Deans from each university were used as key informants resulting in 30 randomly selected Deans being included in the study.

The researcher asked all the respondents the same question; "In your opinion, what are the reasons leading to the current status of doctoral education in Zimbabwe?" The telephonic interviews lasted for a maximum of ten minutes each.

\section{Results}

The results are presented according to the five research questions.

\subsection{Universities in Zimbabwe that offer doctoral programmes}

Table 1 shows the universities offering or not offering doctoral programmesin Zimbabwe.

Table 1. Universities offering or not offering doctoral programmesin Zimbabwe

\section{Name of university}

\section{Doctoral Programmes}

\section{Public/State Universities}

1 Bindura University of Science Education (BUSE)

2 Chinhoyi University of Technology (CUT)

3 Great Zimbabwe University (GZU)

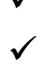

4 Harare Institute of Technology (HIT)

$\mathrm{X}$

5 Lupane State University (LSU)

6 Midlands State University (MSU)

7 National University of Science \& Technology (NUST)

8 University of Zimbabwe (UZ)

9 Zimbabwe Open University (ZOU)

\section{Private Universities}

1 Africa University (AU)

$\mathrm{X}$

2 Catholic University in Zimbabwe (CUZ) X

3 Reformed Church University (RCU) X

4 Solusi University (SU) X

5 Women's University in Africa (WUA) X

6 Zimbabwe Ezekiel Guti University (ZEGU) X X

\section{Doctoral programmes offered $\quad X$ Doctoral programmes not offered}

Table 1 shows that six public universities out of the 15 registered universities in Zimbabwe offer doctoral programmes. None of the six private universities offer doctoral programmes.

\subsection{Disciplines in which doctoral studies are offered in local universities}




\section{Macrothink}

Table 2 shows the disciplines in which doctoral studies are offered in the six local universities

Table 2. Doctoral disciplines offered by the universities that offer doctorates

\section{Discipline}

\begin{tabular}{lcccccc}
\hline & BUSE & CUT & MSU & NUST & UZ & ZOU \\
Agriculture & $\checkmark$ & $\checkmark$ & $\checkmark$ & X & $\checkmark$ & $\checkmark$ \\
Arts & X & $\checkmark$ & X & X & $\checkmark$ & $\checkmark$ \\
Commerce/Business Management & $\checkmark$ & $\checkmark$ & $\checkmark$ & $\checkmark$ & $\checkmark$ & $\checkmark$ \\
Education & $\checkmark$ & $\checkmark$ & $\checkmark$ & X & $\checkmark$ & $\checkmark$ \\
Engineering & X & X & X & X & $\checkmark$ & X \\
Health Science & X & X & X & X & $\checkmark$ & X \\
Humanities \& Social Sciences & X & X & $\checkmark$ & X & $\checkmark$ & $\checkmark$ \\
Science \& Technology & X & $\checkmark$ & X & X & $\checkmark$ & $\checkmark$ \\
Veterinary Science & X & X & X & X & $\checkmark$ & X \\
\hline
\end{tabular}

$\checkmark$ Discipline offered X Discipline not offered

Table 2 shows that the disciplines offered by each university at doctoral level range from one to nine. Engineering, Health Sciences and Veterinary Science disciplines are offered only at one university. Commerce/Business Management doctoral programmes are offered at all the six universities.

\subsection{The share of enrolments and graduation statistics for doctoral students in Zimbabwe}

The total student enrolment in the 15 universities was 85556 in 2014. The doctoral student enrolment in the six universities was 150 representing a share of $0.18 \%$ for doctoral enrolment. Interviews revealed that student enrolments in most the disciplines that offer doctorates were either low or non-existent because of shortages of supervisors who are holders of earned doctorates and preferably at professorial level.

In 2014, the doctoral graduation figures were as follows: National University of Science and Technology (1), University of Zimbabwe (13) and Zimbabwe Open University (14). This gives a total of 28 doctoral graduates for 2014 against a total of 13956 people who graduated that year. This represents a share of $0.2 \%$ for doctoral graduates. Only one university in Zimbabwe enrolled students from the SADC region. Masters degrees graduates amounted to 2466. The other three universities that offer doctoral programmes have not graduated any person as yet.

Respondents mention that attrition rates are mostly caused by brain drain as supervisors relocate to other institutions or abroad. The effect is that students are left stranded since it is not easy to find alternative supervisors. In addition, student mobility as they move up the career ladder and get too many responsibilities that does not leave time for the rigors of research. 
3.4 Doctoral students resident in Zimbabwe that are pursuing doctoral studies with universities outside the country?

All the 15 universities submitted that they had many of their academic staff members studying for doctoral degrees outside the country. However, the request given to these universities was specifically requesting for lecturers who were full-time academics but also studying on a part-time basis and not those on study leave. The information collected reflected a total number of 565 academics studying mostly with South African universities as well as Zambian universities. The number of these academics per university ranged from 6 to 200 .

\subsection{Reasons for the status of doctoral education in Zimbabwe?}

The reasons given for low doctoral training in Zimbabwean universities are explained below in order of priority as determined by their relative frequency of mention and emphasis by respondents.

\subsubsection{University regulations and ZIMCHE standards}

Programme regulations and procedures in some of the six universities that offer doctoral degree programmes were reported to be so stringent that they acted as a deterrent to doctoral student enrolment and persistence. Most respondents mentioned that if prospective students apply to gain entry into doctoral programmes it could take up to a year for their applications to be considered. For example, a prospective doctoral student stated that "I applied for consideration as a student at two local universities within a space of three years. It is so frustrating that my application to the first university was not even responded to after 12 whole months. When Iapplied to the second university (where I lecture) I was not responded to until I followed up nine months later only to be told that there was no suitably qualified supervisor for my study area. The regulations at my university allow for supervision only by Associate of Full Professors."

Other respondents bemoaned the equally strict standards set by ZIMCHE for doctoral programmes in Zimbabwean universities. "ZIMCHE minimum benchmarks state that the major supervisor for any doctoral student should be a full-time employee of the university offering the programme. The rationale given is that an institutional-based supervisor understands fully the academic context and the regulations and quality standards of the university. In addition, such supervisors tend to be more accessible and committed to their work as they themselves will also be monitored by the university quality assurance system. ZIMCHE also expects each supervisor to mentor a maximum of three doctoral students at a given time. This they argue recognises the other tasks the supervisor has for other key duties. As you can imagine these guidelines make it an uphill task for the many Masters holders in universities, government and industrywho are doctoral aspirants. Some people end up studying with all sorts of institutions of varied recognition and status. The challenge is that upon completion of studies, ZIMCHE has to assess the foreign acquired qualifications and needless to say many people find themselves with worthless or bogus qualifications. 
Another respondent said, “.... I ended up enrolling with the University of Lusaka. However, what is surprising is that they do not use supervisors from their university but rely on experts from other universities and industry. In fact I was allocated a supervisor based in Zimbabwe!" Yet another respondent had this to say. "I communicate with my supervisor through email, Viber and even on Whats App. I do not have to travel to the university where I am enrolled (2000km away)it is the supervisor who visits me and other doctoral students at my university. That is what I call user friendliness at the highest level. I will soon be able to realise my dreams."

\subsubsection{Shortage of supervisors}

A critical shortage of senior and appropriately qualified supervisors is evident in most universities in Zimbabwe. The effects ofbrain drain are still being felt even though some universities have managed to attract lecturers with doctorates. Some respondents averred that some of the doctoral degree holders are themselves novices in the area of supervision, research and publication. However, the major problems related to the small numbers of doctoral holdersas well as the high teaching and supervisory loads that they have at Mastersdegree level where they form the core staff. Another critical area mentioned is the lack of incentives given for academics for research and supervision. They end up taking money from their meagre salaries to fund research and publication in order to get promoted but they are not motivated to train others to join their ranks.

\subsubsection{Unavailability of doctoral programmes at many of the local universities}

Many prospective doctoral students are frustrated by the unavailability of doctoral programmes at many of the local universities.

\subsubsection{Inadequate funding and resources}

Inadequate funding for research was a major deterrent for the people in the science, engineering and technology disciplines. The nature of their research calls for expensive equipment and consumables as well as frequent visits to study sites. Most universities do not allocate money for research.

\section{Discussion}

The findings showed that six out of the 15 universities $(60 \%)$ were offering programmes at doctoral level in 2014 giving a share of $0.2 \%$. Similar results have been reported elsewhere in Africa where undergraduate programmes have been described as the bread-and-butter of university education (IAC, 2004). The pooled doctoral degree enrolment for the six universities was 150 translating to a share of $0.18 \%$ of the total student enrolments. A total of 28 people graduated with doctorates from Zimbabwean universities in 2014 . These findings resonate well with the report by IAC (2004) which stated that doctoral degree programs are facing severe neglect. Other studies showed that in the few universities that provide doctoral education, the number of doctoral graduates per year ranged from zero to 40 (Kotecha et al, 2012; Macgregor, 2013).In fact, Kotecha et al (2012) reporteda 1\% share of doctoral student enrolments in SADCand only $0.17 \%$ if South Africa is excluded. 
Approximately 565 academics from Zimbabwean universities were pursuing doctoral degrees at universities in the region notably in South Africa and Zambia and only one university in Zimbabwe enrolled students from the region. The reasons for this state of affairs in order of priority included: the stringent regulatory environment regarding doctoral study in Zimbabwe; shortage of supervisors due to brain drain; unavailability of doctoral programmes at $60 \%$ of the local universities; and inadequate funding and resources. The stringent regulatory environment existing in Zimbabwe whilst having best quality intentions, appear to be a situation of 'shooting oneself in the foot' as demonstrated by the fact that other countries in the region are capitalising on the opportunity created by the apparent regulatory inflexibility. Muriisa (2015) carried out a study on the experiences and key challenges of doctoral education at Ugandan universities. He reported that whilst many students took advantage of the advances in information technology to rely on remote supervision by distant supervisors, success rates were limited. The researcher argued that one-on-one contact is required in order to build confidence, inspiration and a stronger relationship between the student and the supervisor.

The shortage of supervisors and their intensive involvement in Masters degree training programmes made it very difficult to get sufficient supervisors in the Zimbabwean context. The major role of supervisors is to lead doctoral learners through the tortuous path towards mastering knowledge, research and independent/critical thinking skills in the area of study. Dysthe (2002) asserts that the key responsibility of a supervisor is to facilitate the development of learners' research capabilities and mastery of verbal and written communication in their discipline.Muriisa (2015) also reported a critical shortage of supervisors in Uganda.He argued that whilst supervisors in the region were few, networking could harness the few supervisors who are willing and able to supervise doctoral students. However, satisfactory motivation of these supervisors presents a huge challenge. In Zimbabwe the major challenge of engaging remote supervisors is the current regulatory environment. The problem of financial and resource inadequacies to carry out research will still stand out even if the issue of supervisors is resolved.

\section{Conclusion}

The paper concludes that the current state of affairs in doctoral education does not augur well for Zimbabwe's academic and developmental needs and should thus be attended to urgently. Therefore, in view of the status of doctoral programmes in Zimbabwe identified by the study as well as the critical human resources needed to catalyse the success of the Zimbabwe Agenda for Socio-economic Transformation (ZimASSET), the study recommends that ZIMCHE and universities should revisit their standards and regulations taking into consideration realities on the ground. In addition, the Zimbabwe government needs to adequately remunerate university staff and provide funding for research and doctoral studies.

\section{References}

Albertyn, R.M., Kapp, C.A., \& Bitzer, E.M.(2008).Profiling exiting postgraduate students' performance and experiences. South African Journal of Higher Education, 22(4), 749-772. 
Ali, A., \& Kohun, F. (2006). Dealing with isolation feelings in IS doctoral programs. International Journal of Doctoral Studies, 1, 21-33. [Online] Availablehttp://www.ijds.org/Volume1/IJDSv1p021-033Ali13.pdf.

Barnes, B.J. (2010). The Nature of Exemplary Doctoral Advisors' Expectations and the Ways They May Influence Doctoral Persistence. Journal of College Student Retention: Research, Theory \& Practice 11(3), 323-343. http://dx.doi.org/10.2190/CS.11.3.b

Berelson, B. (1960). Graduate education in the United States. The University of Michigan: McGraw Hill.

Bhushan, S. (2007). Doctoral Education in India.In: The Doctorate Worldwide, (eds) H. Green \&S. Powell pp. 168-180. Open University Press - McGraw-Hill Education in the Society for Research in Higher Education (SRHE), England.

Bowen, W., \& Rudenstine, N. (1992). In pursuit of the Ph.D. Princeton, NJ: Princeton University Press. http://dx.doi.org/10.1515/9781400862474

Brown, P.A. (2008). Presidential leadership: Understanding the influence of academic disciplines. Public Purpose, 9-13.

Bunting, I., \& Sheppard, C. (2012). Doctoral Enrolments and Graduation in South Africa. Centre for Higher Education Transformation (CHET).

Callejo-Pérez, D.M., Fain, S.M., \& Slater, J.J. (2011).Higher education and human capital: Re/thinking the doctorate in America. Rotterdam: Sense

Castells, M. (1993).The University System: Engine of development in the new world economy. In: A Ransom, S-M Khoo and V Selvaratnam (eds), Improving Higher Education in Developing Countries. Washington DC: The World Bank.

Cloete, N., \& Maassen, P. (2015).Knowledge Production and Contradictory Functions in African Higher Education

Cloete, N., Sheppard, C., Bailey, T., \& MacGregor, K. (2015).South Africa as a continental $\mathrm{PhD}$ hub?University World News [Online] Availablewww.universityworldnews.com/article.php?story=20150301083352152.

Commission of TheEuropean Communities (2003). Communication from The Commission to The Council and The European Parliament.Researchers in the European research area: One profession, Multiple careers. Brussels.

Consedine, N.S., \& Magai, C. (2006). Emotion development in adulthood: A developmental functionalist review and critique. In C. Hoare (Eds.), The Oxford handbook of adult development and learning (pp. 209-244). New York, NY: Oxford University Press

Cyranoski, D., Gilbert, N., Ledford, H., Nayar, A., \& Yahia, M. (2011).The PhD Factory: The world is producing more PhDs than ever before. Is it time to stop? Nature, 472, 472-979. 
Davis, H., Evans, T., \& Hickey, C. (2006). A knowledge-based economy landscape: Implications for tertiary education and research training in Australia. Journal of Higher Education Policy and Management, 28(3), 231-244. http://dx.doi.org/10.1080/13600800600979983

Dysthe,E.F. (2003). PhD Completion in Canadian Universities.Final Report. Halifax, Nova Scotia: Graduate Students Association of Canada.

Esping, A. (2010). Motivation in doctoral programs: A logotherapeutic perspective. The International Forum for Logotherapy, 33, 72-78.

Gadinger. (2012). Madagascar. In: A Profile of Higher Education in Southern Africa:National Perspectives. Kotecha P (exec. ed.), M. Wilson-Strydom\& S.M.Fongwa (eds) Volume 2 Johannesburg: SARUA.

Gardner, S.K. (2008). Fitting the mold of graduate school: A qualitative study of socialization in doctoral education.Innovative Higher Education, 33(2), 125-138. http://dx.doi.org/10.1007/s10755-008-9068-x

Gardner, S.K., \& Gopaul, B. (2012).The part-time doctoral student experience. International Journal of Doctoral Studies 7, 63-78.

GarweE.C. (2013). Quality assurance challenges and opportunities faced by private Universities in Zimbabwe. Journal of Case Studies in Education, 5.

Garwe E.C. (2015). Managing the Quality of Cross-Border Higher Education in Zimbabwe. Journal of Education and Training Studies, 3(2), 44-50. http://dx.doi.org/10.11114/jets.v3i2.634

Gilliam, J., \&Kitronis, W.A. (2006). National implications: The hidden nature of doctoral student attrition. National Journal for Publishing and Mentoring Doctoral Student Research, $3,1-7$.

Golde, C.M. (2000). Should I stay or should I go? Student descriptions of the doctoral attrition process.The Review of Higher Education 23(2), 199-227. http://dx.doi.org/10.1353/rhe.2000.0004s

Golde, C.M. (2005). The role of the department and discipline in doctoral student attrition: lessons from four departments. The Journal of Higher Education, 76, 669-700. http://dx.doi.org/10.1353/jhe.2005.0039s

Gorman, C. (2013). Talent and Human Capital: Why it determines today's business success. Times Literary Supplement.

Hadjioannou, X., Shelton, N.R., Fu, D., \& Dhanarattigannon, J. (2007). The road to a doctoral degree: Co-travellers through a perilous passage. College Student Journal, 41(1), 160-177.

Halvosen\&Mwind, M. (2010). Reshaping Research Universities of the Nile region, Kampala, Fountain Publishers. 
Harle, J. (2013). Doctoral Education in Africa. Assiciation of Commonwealth Universities. United Kingdom.

Hawlery, P., (2003). Being bright is not enough: the unwritten rules of doctoral study Springfield, Illinois: Thomas.

Herman, C. (2011). Obstacles to success-Doctoral student attrition in South Africa. Perspectives in Education, 29(3), 40-52.

Hortulanus, R., Machielse M., \&Meeuwesen, L. (2006). Social isolation in modern society. New York, NY: Routledge.

IAC Report (2004). Creating and retaining a new generation of agricultural scientists In: Realizing the Promise and Potential of African Agriculture102-179.[Online] Available http://www.interacademycouncil.net/24026/AfricanAgriculture/26214.aspx.

Ivankova, N.V., \& Stick, S.L. (2007). Students' persistence in a distributed doctoral program in educational leadership in higher education: A mixed methods study. Research in Higher Education, 48(1), 93-135. http://dx.doi.org/10.1007/s11162-006-9025-4

Jairam, D., \&Kahl Jr., D.H. (2012).Navigating the doctoral experience: The role of social support in successful degree completion.International Journal of Doctoral Studies, 7, 311-329.

Jiranek, V. (2010).Potential predictors of timely completion among dissertation research students at an Australian faculty of sciences.International Journal of Doctoral Studies 5, $1-13$.

Kim, D. \&Otts, C. (2010). The Effect of Loans on Time to Doctorate Degree: Differences by Race/Ethnicity, Field of Study, and Institutional Characteristics.Journal of Higher Education 81(1), 1-32. http://dx.doi.org/10.1353/jhe.0.0079

Kotecha, P., Steyn, A.G.W.\&Vermeulen, P.J., (2012). The status quo of doctoral education in the SADC region. SARUA Leadership Dialogue Series 4(1) 16-24.

Lee, C. J. (2009). The experience of nurse faculty members enrolled in doctoral study. International Journal of Doctoral Studies, 4, 59-75. [Online] Available http://www.ijds.org/Volume4/IJDSv4p059- 075Lee255.pdf

Leonard, D., Becker, R., Coate, K.(2005). To prove myself at the highest level: The benefits of doctoral study. Higher Education Research and Development, 24(2), 135-149. http://dx.doi.org/10.1080/07294360500062904

Lewis, C.W., Ginsberg, R., Davies, T., \& Smith, K. (2004).The experiences of African American Ph.D. students at a predominantly white Carnegie I - research institution. College Student Journal, 38, 231- 245.

Lovitts, B. \& Nelson, C.(2000). The hidden crisis in graduate education: Attrition from Ph.D. programs. Academe, 86, 44-50. http://dx.doi.org/10.2307/40251951 
Lott, J., Gardner, S.K., \& Powers, D.A. (2009). Doctoral student attrition in the STEM fields: An exploration of event history analysis. The Journal of College Student Retention, 11, 247-266. http://dx.doi.org/10.2190/CS.11.2.e

Lovitts, B.E. (2001). Leaving the ivory tower: The causes and consequences of departure from doctoral study. Lanham, UK: Rowman \& Littlefield Publishers.

Lynam, J. K., and M.J. Blackie. 1994. Building effective agricultural research capacity: The African challenge. In: Anderson, J. R. (Ed.) Agricultural technology: Policy issues for the international community. Wallingford, U.K.: cab International.

Macgregor, K. (2013). University World News (300), 7. [Online] Availablehttp://www.universityworldnews.com/article.php?story=20131215083250788.

MoHTE (Ministry of Higher and Tertiary Education), (2010).Baseline study on the status of human capital development and training institutions in Zimbabwe.Machawira, M.S. (ed.)

Mouton, J. (2011). The State of Doctoral Training in sub-saharian Africa: Statistics, Analysis and Challenges. AAU Conference of Rectors, Vice-Chancellors \&Presidents (COREVIP).Stellenbosch. [Online] Available http://events.aau.org/userfiles/file/corevip11/presentations/state_of_dotoral_training.pdf.

Mujtaba, B.G., Scharff, M.M., Cavico, F.J., \&Mujtaba, M.G. (2008). Challenges and Joys of Earning a Doctorate Degree: Overcoming the "ABD" Phenomenon. Research in Higher Education Journal, Vol. 1(1), 10-26. [Online] Available http://aabri.com/manuscripts/08010.pdf.

Muriisa, K.R., (2010). It is not all About Money: Financial Governance and Research in Public Universities in Uganda. In T.Halvosen et al, 2010, Reshaping Research Universities of the Nile region, Kampala, Fountain Publishers.

Muriisa, K.R., (2015). The State of Doctoral Education in Social Sciences in Uganda: Experiences and Challenges of Doctoral Training at Mbarara University of Science and Technology 2003-2010.Journal of Education and Practice, 6(10), 204-213.

Nettles, M.T. \& Millett, C.M. (2006). Three magic letters: Getting to Ph.D. Baltimore, MD: Johns Hopkins University Press.

Oswalt, S., \&Riddock, C. (2007). What to do about being overwhelmed: Graduate students, stress and university services. College Student Affairs Journal, 27(1), 24-44.

Park, C. (2005). New Variant PhD: The Changing Nature of the Doctorate in the UK. Journal of Higher Education Policy and Management, 27(2), 189-207. http://dx.doi.org/10.1080/13600800500120068

Powell, S., \& Green, H. (2007).The doctorate worldwide. Maidenhead: Society for Research into Higher Education \& Open University Press 
Stevens-Long, J., Schapiro, S.A. \&McClintock, C. (2012).Passionate Scholars: Transformative Learning in Doctoral Education. Adult Education Quarterly, 62(2), 180-198. http://dx.doi.org/10.1177/0741713611402046

Thune, T. (2009). Doctoral students on the university-industry interface: a review of the literature, Higher Education, 58, 637-651. http://dx.doi.org/10.1007/s10734-009-9214-0

Walker, G., Golde, C.M., Jones, L., Bueschel, A.C., \& Hutchings, P. (2008). The formation of scholars: Rethinking doctoral education for the twenty-first century. Stanford, CA: Jossey-Bass.

Wao, H. O. (2010). Time to the doctorate: Multilevel discrete-time hazard analysis. Educational Assessment, Evaluation and Accountability, 22(3), 227-247. http://dx.doi.org/10.1007/s11092-010-9099-6

ZIMCHE (Zimbabwe Council for Higher Education). (2015). Enrolment and graduation statistics for universities in Zimbabwe. 